This item was submitted to Loughborough's Research Repository by the author.

Items in Figshare are protected by copyright, with all rights reserved, unless otherwise indicated.

\title{
Brave new brains: sociology, family and the politics of knowledge
}

PLEASE CITE THE PUBLISHED VERSION

http://dx.doi.org/10.1111/1467-954X.12374

PUBLISHER

() John Wiley \& Sons

\section{VERSION}

AM (Accepted Manuscript)

\section{PUBLISHER STATEMENT}

This work is made available according to the conditions of the Creative Commons Attribution-NonCommercialNoDerivatives 4.0 International (CC BY-NC-ND 4.0) licence. Full details of this licence are available at: https://creativecommons.org/licenses/by-nc-nd/4.0/

\section{LICENCE}

CC BY-NC-ND 4.0

\section{REPOSITORY RECORD}

Gillies, Val, Rosalind Edwards, and Nicola Horsley. 2019. "Brave New Brains: Sociology, Family and the Politics of Knowledge". figshare. https://hdl.handle.net/2134/21553. 


\title{
Brave New Brains: Sociology, Family and the Politics of Knowledge
}

\author{
Val Gillies, Rosalind Edwards and Nicola Horsley
}

\section{Sociology and the biological re-turn}

The crisis narrative evident within social science has led many to re- emphasise the materiality of the body and call for the forging of new alliances with the life sciences. Some have explicitly sought to utilize biological accounts as a more authoritative foundation upon which to ground theoretical claims (Massumi 2002, Thrift 2007). Others have recommended realignment towards the intersection of the social and natural sciences with the aim of countering stagnation and reflecting new discoveries and preoccupations (Franks 2010, Christakis 2013). More specifically, a number of sociologists are welcoming a new turn toward the social within the rapidly developing field of biology, identifying this as an opportunity for productive dialogue and collaboration (Rose 2013; Meloni 2013, 2014; Fitzgerald et al 2014, Fuller 2014). Such theorists trace the roots of sociology back to a $19^{\text {th }}$ century appreciation of biology, portraying the two disciplines as 'estranged twins' (Fitzgerald 2014) with much to gain from a contemporary re-union.

For example, Meloni (2013) hails a 'postgenomic age' in which nature / nurture divides are invalidated as part of an increasing socialisation of the biological. As he notes, 'pro-social' views are colonising evolutionary perspectives. Neuroscientists now study the social brain, while epigenetic research is revealing the social and environmental mediators of gene expression (Meloni 2013, 2014). In the words of Steve Fuller, interviewed after his keynote at the British Sociological Association 2014 Annual Conference, 'biology ain't what it used to be ${ }^{1}$ '. Meanwhile social theorists seeking to escape the conceptual dead end associated with the disembodied social constructionism are turning to the material foundations of the life sciences. Signs of a biosocial language are emerging in the social sciences (Meloni 2014) channelling a transcendent 'hopeful ethos' associated with new styles of thought in the life sciences. Rose and AbiRached (2013) point to understandings of plasticity that now dominate neuroscience with the brain regarded as 'optimizable' and biology viewed in terms of possibilities rather than destiny. In refuting reductionism and determinism these new biologies are put forward as potentially radically transformative, providing the tools to challenge a hegemonic politics of the individual by offering new solutions for social betterment.

Cross discipline collaboration is also urged by those seeking to revitalise the discipline. Sociologists, it is argued, have an important role in realising the 'deeply progressive implications' that could emerge when 'cosmopolitan and emancipatory forms of politics' flow beyond the life sciences into policy (Fitzgerald et al 2014). For Rose (2013) this entails 'moving beyond description, commentary and critique, beyond the study of downstream implications of biology and biomedicine' (23), to develop new affirmative relations. This requires transcending the horrifying legacy of eugenics to recognise that contemporary biopolitics now revolves around life rather than death, with new molecular understandings directed towards physical and mental enhancement (Rose 2007). To quote Fuller again:

'the thing that made eugenics so scary was the idea that this was a kind of esoteric form of knowledge that scientists, in collusion with the state might use to somehow mastermind getting rid of certain classes of people and introducing another class of people. We really don't live in that kind of world anymore'2.

\footnotetext{
${ }^{1}$ Quoted in Network Magazine, British Sociological Association Issue 117 (2014) p 18

${ }^{2}$ Quoted in Network Magazine, British Sociological Association Issue 117 (2014) p 18
} 
Such confidence in $21^{\text {st }}$ century biology might seem a tad misplaced to many in the context of global financial upheavals, political instability in Europe (including far right populism) and routine mass surveillance and biometric marking of populations. Nevertheless, this claim reflects a more general cultural and academic embrace of scientific innovations as paving the road to social progression (Rose 2007). For example, the Economic and Social Research Council have invested in birth cohort studies that collect biomarkers from participants ${ }^{3}$. They have also directed award funding toward epigenetics research, identifying it as a key emerging platform to assess health and social policy implications ${ }^{4}$, with educational neuroscience similarly promoted as an area most likely to deliver strategic priorities ${ }^{5}$. The biomedical research charity the Wellcome Trust appears to share this vision, allocating $£ 6$ million to develop neuroscience insights into classroom education. And while popular science writers and transhumanists speculate on the revolutionary potential of such approaches to address longstanding social problems (eg Doidge 2015; Fuller 2013; Carey 2012), the Big Lottery Fund has invested in an evaluation of early years services, including the collection of biomarkers from disadvantaged children to measure 'epigenetic changes'6.

In the midst of this enthusiasm for the biosocial we wish to sound a note of caution. Without doubting the relevance of a corporal material perspective or the potential for fruitful cross disciplinary collaboration, we call for a more critical consideration of the assumptions and politics underlying calls for sociologists to connect with a life sciences agenda. More specifically, we consider the repercussions for the 'certain classes of people' living under a contemporary 'biopolitics of life'. Drawing in particular on the biologised policy trope of early years intervention, we show how biosocial visions tend to solidify and make normative specific relational practices and behaviours. The shift from the selfish gene to the social brain has been characterised by new understandings of homo-economicus as socially incubated, reinforcing gendered, classed and racialized accounts of family competence and individual value. Building on this analysis we question the role that sociologists might play in realising an emancipatory biosocial politics from within the grip of neoliberal moralisation of hope and self-transformation.

\section{Who's social is it anyway?}

The social at the heart of sociological enquiry has always been subject to debate and contention. As many have noted social science instruments and techniques are constitutive, bringing the object of study into view, categorising and shaping how it is thought about and known (Osborne et al 2006; Law and Urry 2004). This politics of method framed the development of classical sociology, the institutionalisation of the discipline in the context of the post war settlement and more recently an existential questioning of the purpose and function of social science in a new age of social data availability (Savage and Burrows 2007, 2009, 2014; Osborne et al 2008). In this context the observation that biologists are discovering and increasingly incorporating an understanding of the social necessarily prompts the question what kind of social? As biosocial advocates acknowledge, the social currently reanimating the life sciences bears little resemblance to anything sociologists might recognise. For example, Fitzgerald and Callard (2014) describe

\footnotetext{
${ }^{3}$ For instance the studies brought together under the 'Closer' initiative http://www.closer.ac.uk/about/, as well as the ill-fated 'Lifestudy' http://www.lifestudy.ac.uk/homepage

${ }^{4}$ ESRC-BBSRC joint research call on Epigenetics 2014/15 http://www.esrc.ac.uk/funding-and-guidance/fundingopportunities/32152/esrcbbsrc-joint-research-call-on-epigenetics-201415.aspx

${ }^{5}$ See Review of Strategic Priorities http://www.esrc.ac.uk/about-esrc/mission-strategy-priorities/refiningpriorities/index.aspx

${ }^{6}$ See A Better Start From competition to collaboration: key messages

https://www.biglotteryfund.org.uk/betterstart
} 
their 'painful awareness' that the social invoked is a 'rather mangy-looking beast - an animal quite alien to the rich and fat understanding of a century-old anthropology or sociology' (6).

More relevant still, the limited social province of the biological is assembled as a natural, apolitical space, with little consideration of the normative interpretations producing it. Sociologists familiar with Bourdieu's 'construction of the object' well recognise social knowledge as drawn from already existing frameworks of historically, culturally and politically specific meaning (Bourdieu and Wacquant 1992). But biologists working at the level of the molecular are less prone to question the normative contentions shaping scientific agendas and interpretations of findings. For example, much of the enthusiasm generated in relation to the rapidly growing field of behavioural epigenetics revolves around Michael Meaney's work on the 'mothering' practices of rats. Meaney has demonstrated epigenetic differences in gene expression between rat pups who were licked and groomed frequently by their mothers and those that were not, and has provided evidence that such mutations and 'mothering behaviour' are inherited by subsequent offspring.

While behavioural epigenetic findings have been subject to much discussion and critique ${ }^{7}$, scientists have scaled up findings about rat 'mothering' and gene profile to the human world (eg Monk et al 2012, McGowan and Szyf 2010). Indeed, Meaney himself applies his research to disadvantaged children, stating:

Our research has identified a key, early environmental factor which produces enduring biological changes in brain development and changes in behaviour that are crucial to lifetime outcomes. We have found that the biological process is potentially reversible, holding out considerable hope that children's lives can be dramatically improved through well-targeted supports. Our findings suggest that social policy could soon be on a par with general medicine in being able to structure help that is appropriate to the needs, biology and responsiveness of each child. (Meaney 2014, unpaginated)

Leaving aside the technical complexities informing this debate, the core focus of the research inevitably builds on and reinforces deeply engrained ideas about cycles of deprivation and the culpability of mothers. Maternal behaviour is commonly positioned at the interface of the social and biological, reflecting not only gendered assumptions but also a set of late modern contentions about parenting as profoundly formative of individual life chances. This is notwithstanding the pragmatic concentration on the interpersonal within biosocial research 'because that is all the sociality that can enter the experimenters' purview' (Rose and Abi Rached 2013, 159).

It is worth noting at this point that controversies around epigenetics rage with many scientists decrying the 'hype' surrounding the field (Juengstemail 2014). Pickersgill et al (2013) note the uncertainty and ambivalence characterising epigenetic debates, pointing to the way "tentative "coulds" and hopeful "mays" commonly steer these narratives' (434). The neurogeneticist, Kevin Mitchell (2014) is less equivocal in his assessment of murine epigenetic findings, critiquing much of the science and mocking their implications.

Evolution appears to have made us mammals very delicate creatures. If you look sideways at a mouse these days you can permanently alter its genes, it seems, along with those of its kids and grandkids. Of course, you'd think another look might change them back if they're so sensitive, but apparently not.

\footnotetext{
${ }^{7}$ For example see The Trouble with Epignetics by Kevin Mitchell http://www.wiringthebrain.com/2014/04/thetrouble-with-epigenetics-part-3.html
} 
The scientific intricacies underpinning behavioural epigenetics continue to be extensively discussed alongside concerns about generalising to human behaviour. What tends to remain unquestioned in scientific circles though is the rationale structuring the focus on rat mothers and the social meanings implicit in such a focus. An invisible normative framework guides both the research and its critical reception. For example, an article published in the journal Science by Greg Miller (2010), provides a measured account of findings beyond the 'seductive allure of behavioural epigenetics'. Yet Meaney's work is addressed in the paper under the sub-heading, 'The importance of a loving mother'. The subsequent discussion highlighting the scant evidence for translating epigenetic findings to humans is accompanied by a box of four images titled 'Different upbringings' (see Figure I) with the top two featuring photographs of rats feeding pups. In the second of these the rat mother looks away disinterestedly (or as disinterested as a rat can look). Underneath are contrasting images of rich and poor US neighbourhoods. The caption reads:

Being raised by a nurturing (top left) or a lackadaisical (top right) mother can cause epigenetic differences that affect a rat pup's behavior later in life. Whether similar differences occur in people raised in wealthy (bottom left) or impoverished (bottom right) neighbourhoods remains an open question. (25)

Aside from the implicit biological universalism of emphasising the particular significance and accountability of mothers, the unproblematic conflation between impoverishment and so called 'lacksadasical' mothering effectively highlights how principles quickly become elided, assumptions naturalised and alternative explanations obscured. This tacit reasoning is further contextualised by the racialized make up of US neighbourhoods, cross cut by social class, which remains an unspoken backdrop to the discussion (e.g. Massey et al. 2009).

\section{INSERT FIGURE 1 ABOUT HERE}

As Bourdieu (1992) notes, research topics and discussions are trapped within pre-existing meanings in the absence of a reflexive sociology. Moreover, the social conceived of within the life sciences centres the (interpersonally embedded) individual, placing her at the centre of social problems and solutions. And the normative undercurrent within biosocial models is intensifying as a result of what Rose and Abi-Rached (2013) have termed the 'translational imperative'; the pressure to satisfy funders by producing meaningful, applicable findings. This has seen an emphasis on identifying the biomarkers of child rearing, chiming neatly with a broader policy drive to personalise poverty, inequality and other social problems.

As neurofeminist theorists Höppner and Schmitz (2014) contend:

Within the current popular debate, what stands out in particular is the paradigm of individualization and self-responsibility in neoliberal society. Equal opportunities qua the optimization of brains are addressed in the sense of 'everyone is his/her own fortune. (14).

Humankind may now be envisaged as a socially adaptive species at the molecular level, but values, strengths and visions of progress are still relentlessly tied to a late capitalist ideology. To illuminate this point we draw on the example of early years intervention as a contemporary social policy tenet that is articulated and justified through the language of biology. As the social is routinely reduced to the interpersonal in the laboratory the 'social problem' is reduced to the level of the family in social policy. We begin by outlining how parenting and child development have come to be positioned at the core of new conceptions of the social, before highlighting the mechanisms through which the life sciences are funnelled through a neoliberal politics of the social. 
As Gane (2014) demonstrates, the trajectory of the economic liberalism that came to exert such global power and influence began in dialogue with early sociology and developed through an explicit critique of the notion of the social underpinning the discipline. Suspicion was cast upon claims that 'society' has any independent material existence beyond the statistics used to envisage it. From the perspective of Friedrich Von Hayek and other neoliberal pioneers, social scientists and the state conjured up a reified collective as part of a projection of socialist ideals (Davies 2013). Society, it was argued, has no agency and cannot be independently known except through market based choices of individuals. Much has been written by social theorists on the neoliberal project and its associated aversion toward collective social conceptualisations. However, far less attention has been focused on the fundamental but largely invisible role understandings of family as an indispensable and undeniably social concept have played in developing this political direction.

Margaret Thatcher's infamous statement that 'there is no such thing as society.... There are individual men and women, and there are families ${ }^{8}$, reflected both the moral anxieties of those on the political right but also the undeniable interdependencies of individuals particularly towards the beginning and end of life. Even the most ardent individualist cannot transcend the inevitability of human frailty. More pertinent to this argument, human beings are not born 'entrepreneurs of the self' but must be made into self-governing entities within the social realm of family. This recognition has profoundly shaped neoliberal reconfigurations of the state and society, and can be traced right through into the narrow and anaemic biological conceptions of the social operationalised within the laboratory. As Rose and Abi-Rached (2013) acknowledge broad arrays of childhood interactions are routinely scaled down to the level of interpersonal primary caregiver relations, with 'the social' reduced to the common denominator of mother--child interactions.

While Thatcher was vocal about the importance of 'the family', the traditional values she and others on the political right lauded during the 1970s and 80 s reflected and reproduced an old capitalist order. The manifest gender hierarchy and oppression underpinning embedded liberal ideals of the nuclear family ill fitted the rhetoric of individual freedom and liberation proselytized through the 'new spirit of capitalism' (Boltanski and Chiapello 2005). Nancy Fraser (2009) makes a salutary point for those extolling the biosocial when she argues that feminist emancipatory ideals and critiques of 'the family' were appropriated and made mainstream, achieving very different political ends from those intended. The concept of the personal as political increasingly became articulated as the personal is the only political, enforced through promotion of the self-determining, networked individual, liberated from gendered and classed expectations and ties.

A reconstructed ideology of family, better suited to these advanced capitalist sensibilities, emerged as free market economists developed the theory of human capital and applied the principles of rational behaviour to family. Most notably, Becker (1981) conceived of families as 'small factories' (964) producing children and other commodities (including health and prestige). From this perspective families are held together not by obligation or sentiment but by mutual interest. Children are raised as a venture opportunity and become the core focus of production. Although widely critiqued at the time, Becker's conception of human capital as an output of family laid the foundations for a social investment model of policy, subsequently aggressively pursued through the targeting of parenting under the rubric of early years intervention. As such, Becker's representation of families as rational choice driven units shifted over time from a description of how the world worked to a morally charged necessity requiring state enforcement.

\footnotetext{
${ }^{8} 1987$ Sep 23 Interview for Woman's Own ("no such thing as society") http://www.margaretthatcher.org/document/106689
} 
In the context of increasing diversity (rising rates of divorce, cohabitation, birth outside of marriage and same sex parenting) administrative and policy definitions of family became more flexible and inclusive, but crucially through a centring of childrearing as the primary moral concern. The replacement of male breadwinner models of family with norms around dual earning households was promoted as the progressive solution to gender injustice. At the same time the female dominated practice of childcare was redrawn as a motor of meritocracy, moving conceptualisations of family away from traditional structural associations with class bound trajectories. Instead family was hailed as the formative site through which competent personhood is cultivated, with well parented children better able to navigate and capitalise on new post-industrial economic landscapes (Gillies 2014). Concerns about the social fabric were largely condensed down to the interpersonal level of parenting, with a focus on risk reduction through 'early intervention' eclipsing established welfare state principles of need and mutual obligation.

By the end of the $20^{\text {th }}$ century childhood investment was being touted as a prescription for a range of social ills. The US Nobel Laureate economist James Heckman (2000) has played a particularly influential role in normalising a rationale for targeting intervention at the very young. Arguing that human capital is cumulative rather than fixed, Heckman and colleagues proposed a formula summed up in the phrase 'skills beget skills and abilities beget abilities' (Cunha and Heckman, 2007). This economic reasoning, known as the 'Heckman equation', asserted that return on human capital was very high in the early years of life and diminished rapidly thereafter. A re-inscription of family from institution to contingent manufacturing hub followed. Traditionally positioned as outside the remit of state involvement in all but extreme circumstances family came to assume significance as a key vehicle for social policy intervention.

Previous state preoccupations with family values and strengthening the nuclear family as a moral bedrock were largely replaced by an instrumental focus on 'parenting' and 'child outcomes'. In this new political and cultural landscape understandings of inequality, poverty, crime and disorder are increasingly filtered through the lens of bad parenting, with poor families targeted under the auspices of reducing child poverty, crime and anti-social behaviour. The hegemony of this paradigm was particularly evident in the then Government's interpretation of the 2011 English riots as a crisis in parenting skills, with this thesis forming the centrepiece of a policy 'fightback'. Promises that parenting support would be 'accelerated, expanded and implemented as quickly as possible' were pursued through an extension of 'Family Nurse Partnerships' (a home visiting service for disadvantaged pregnant mothers) and the setting up of a 'troubled families taskforce' (Edwards and Gillies 2016).

The notion that family intervention can inoculate against irrationality and personal pathology has similarly gained traction and credibility in academic circles, most notably through the rise of 'prevention science' (eg. see Catalano 2010). This multidisciplinary effort to alter the 'trajectories of poor lifestyle decisions' commonly locate the precursors of dysfunction in early family life. Significantly, while animal behaviour is anthropomorphised to convey the policy implications of epigenetic generating rat 'mothering' practices, the humanising language of family virtually disappears in prevention science with mothers depicted instead as 'primary socialisation agents'. 'Intervention targets' are recommended on the grounds that 'optimal socialisation leads to informed decisions regarding acceptable behaviour when confronted with verbal, behavioural, emotional and environmental cues' (Petras and Sloboda 2014; 257). More broadly then, parenting has come to substitute for discussions of the social, often as a proxy for social class through the ready conflation of poor parenting with poor living standards.

\footnotetext{
9 David Cameron's 'Social Fightback' Speech 15th August 2011 
Parenting: and the new 'social':

As $21^{\text {st }}$ century understandings of family see an emphasis on human capital production through the language of parenting proficiency, a distinctive form of neoliberal paternalism has begun to take root. The rise of psychologically inflected accounts of economic theory and appropriation of the arena of interpersonal relationships to conceptualise and manage socially embedded individuals has been widely discussed (Jones et al 2013; Davies 2015). In particular, burgeoning fields of neuroeconomics and behavioural economics have been explored in relation to an alignment of philosophical and political concerns termed 'neurocapitalism' (Pykett 2013). In the wake of the global financial crisis new attempts have been made to envisage and requisition the social as underpinning and supporting sensible behaviour and 'good' choices, marking a shift away from a rationale of maximising individual preference towards an evaluative agenda prioritising 'good' sustainable choices that promote the political equilibrium (Davies 2012; Soss et al 2011).

Yet while public policy has experimented with psychologised techniques of libertarian paternalism, for example through the UK Government's commissioning of a 'Behavioural Insights Team' (Jones et al 2013) parenting remains the formative and largely uncontested medium through which the state is actively seeking to shape self-regulating, neoliberal subjects. The 'soft paternalism' associated with neurocapitalism calcifies into an authoritarian conviction when applied to the sphere of family justifying the monitoring, regulation and policing of disadvantaged mother's in particular. This is evident through, for example the introduction of developmental checks for two year olds, a creeping formalisation of early years care as an educational space and the increasing use of legislation (including Parenting Orders) to enforce parental compliance. More starkly, family courts are now receiving record numbers of applications from statutory services to remove children from their parents (Puffet 2016), reflecting increasing concern about 'cycles of deprivation' perpetuated through family practices.

With the social envisaged as a tool of self-optimization mastered in infancy childrearing becomes about 'action and skills acquisition rather than a complex web of relationships between adults, children and their communities' (Hartas 2011;148). The effect is to intrumentalise the expression of love for children, with parents urged (and in many cases compelled) to carefully consider and plan how they might touch, maintain eye contact, talk and play with their children for maximum effect (McVarish 2014). In developed economies across the world the minutia of everyday childrearing practice have been harnessed to a moral agenda, with practices like breastfeeding and pursuit of early home learning strategies promoted as aspirational actions that will maximise development and life chances (Faircloth et al 2013). Despite the responsibility for such practices predominantly falling on mothers, this automatic eliding of children's best interests with the best interests of neoliberal regimes goes broadly unchallenged.

The conviction that intensive family intervention in early childhood can improve prospects for the disadvantaged, and for whole nations, is most commonly justified through reference to the economic prediction associated with the Heckman equation. Indeed a graph showing projected 'rates of return on investment in human capital by age' has been widely reproduced in policy circles as if it were proof in itself of the model's contentions (Howard-Jones et al 2012). But the inconveniently underwhelming empirical evidence base for the effectiveness of early years intervention (Hartas 2012; Bruer 2011; Rutter 2007) is now being leapfrogged for a seemingly more reliable and persuasive direction offered by the emerging biological accounts of 'the social', with particular interest centring on the childhood plasticity of the brain and the epigenetic potentiality of parenting.

It is within this narrow and politically loaded context that biosocial explorations of how the environment 'gets under the skin' are developing, making for a somewhat ideologically sodden base upon which to pitch a big, cross disciplinary tent. As we will illustrate in more depth, the emergence of a broad and deep 
consensus around the necessity of cultivating and augmenting children's development in the name of the national good, generates as many moral objections as erstwhile eugenic projects.

\section{Early intervention and the optimal imperative}

In previous work we have demonstrated the extent to which policy and practice discourses of early intervention are now rooted in biological conceptions of neurodevelopment, and increasingly epigenetics (Edwards et al 2015, Edwards et al forthcoming). These conceptions resonate with and operationalise the hope filled ethos recognised by biosocial advocates. The genetic determinism and reductionism of the past are replaced by a conception of early years plasticity through the interaction of brain as biology and the social as parenting. Consequently, when a group of neuroscientists published findings suggesting that children from poor families have smaller brain surface areas compared with their more privileged peers, discussion among the science community and media focused on how this deficit could be addressed through intervention ${ }^{10}$.

This is exemplary of the 'somatic ethic' Rose (2013) identifies as characteristic of the 'new century of biological citizenship'. The social biological interpretations emerging from epigenetic and neurodevelopmental research carry an imperative to act on possibilities through which humanity could be transformed (Rose 2013). Yet reducing the shaping of human subjectivity and destiny down to the molecular level strips imperatives to intervene of the political dimensions that frame them as obligations. As we have intimated, the targets of the interventionist ethos are specific and socially patterned. When Rose and Abi-Rached state that '... we are now acquiring the obligation to take care of our brain - and the brains of our families and children - for the good of each and of all' (2013, p. 223) their collective 'we' is issued in a context where 'care' is heavily gendered and the formative development of infant brains attributed almost entirely to mothers.

The downstream policy and practice implications of such constructions are already profound. Contemporary family policy is riddled with unsupported contentions that the quality of early years care is reflected in the anatomical structure of a child's neural circuits. For example, the Early Intervention Foundation (part funded by the ESRC as an official 'What Works centre') cites crime, poor education levels and job prospects and low quality of life, before suggesting 'science tells us we may find the answer to these complex social problems in early childhood when the architecture of the brain begins to form'. ${ }^{11}$ The significance accorded to early nurturing and attachment in determining or preventing personal and societal dysfunction drives a range of family interventions delivered through pre- and post-natal care provision in poor communities. And as our previous research with practitioners has shown, a strong emphasis operates around the significance of breaking cycles of insensitive and insufficiently attentive parenting among the poor (Edwards et al 2015).

This is achieved through targeting pregnant women and new mothers as the core mediators of their children's development and subjecting them to parenting interventions designed to 'optimise' their children's development. While couched in the gender neutral terminology of 'parenting', early intervention policies and services reflect an essentialist turn towards viewing good motherhood as biologically informed, with some scientists suggesting that mothers' brains are re-programed during pregnancy to increase their emotional sensitivity (Kinsley and Franssen 2010; Pearson and Lightman 2009; Sandman and Glynn 2009). Concern also revolves around the disadvantaged mother's brain as potentially producing too much

\footnotetext{
${ }^{10}$ For example see Huffington Post, Study Reveals Sad Link Between Poverty And Children's Brain Development http://www.huffingtonpost.com/2015/03/30/brain-development-poverty_n_6968758.html

${ }^{11}$ See Brain Hero video http://www.eif.org.uk/what-is-ei/
} 
of the stress hormone cortisol and adversely affecting the neural development of the foetus. This plays out through appeals to pregnant mothers coping with poverty, housing insecurity and domestic violence, to better control their anxiety by considering what getting stressed might do to their baby ante and post natally (Edwards et al 2015).

Such explicitly gendered and classed accounts of socially sculpted brains and genes highlight the need for sociologists to continue challenging and critiquing in any collaboration with life scientists. Just as ends did not justify means in more deterministic eras, normatively engrained assumptions are no less dangerous in the post genomic age. In this context a disciplinary move beyond the downstream of policy and practice risks being read as a retreat from the politics of the social toward the apparent blind objectivity of the molecular gaze. Adopting such a perspective could obscure configurations of domination and oppression beneath a progressive will to enhance the future and make a better world. Critical consideration of the values driving interventions are rendered redundant in an age where biological truth is seen to speak for itself.

\section{The logic of capital and the tyranny of hope}

It is from this critically embedded position that we take issue with the optimistic promises some are reading into biosocial synthesis. We also question the substance and meaning of the hope that is generated through such a somatic ethic. A non-deterministic commitment to opportunity rather than destiny has been broadly welcomed, with little consideration of the negative consequences this standpoint could unleash. As Rose and Novas (2007) suggest, the biological citizenship characterising contemporary regimes of the self generates 'a moral economy of hope, in which ignorance, resignation and hopelessness in the face of the future is deprecated'(6). In the process individuals are forced into a relational dynamic that Lauren Berlant (2011) has described as 'cruel optimism'. Biological and social limitations are overridden by attachments to damagingly unrealistic possibilities that carry a high psychic and social cost. Those caught within this dynamic struggle on toward the unattainable rather than resisting the regime, grinding themselves down in process. Thus, for the mother in the crosshairs of early intervention programs the careful adherence to optimal parenting is sold as a realisable future investment, bypassing the structural and social conditions that will almost inevitably seal her children's fate.

From this perspective, hope and its attendant practices (trying, persevering, managing disappointment) sit closer to oppression than freedom. Indeed it could be argued that a moral obligation to strive and selfimprove has intensified a merciless pressure on the poor, sick and vulnerable to personally overcome their predicaments. Acceptance of limited capacity and responsibility has been swept away with the determinism of the past placing new normative burdens on those least able to manage them. Aggressive welfare reform might be held up as another corollary of this biopolitics of life and its attendant tyranny of hope. Notoriously callous 'fitness to work assessments' stripping the severely disabled and even the terminally ill of Disability Living Allowance are born of a 'hopeful' asset based approach to public health ${ }^{12}$ (Friedli 2014). Biosocial research is being conducted against the backdrop of a mission to capitalise the self, with moral identity made contingent on the active demonstration of resilience and determination to progress, regardless of disadvantage or incapacitation. While no one is written off or rendered hopeless anymore, the concept of dependency is disavowed both as a subject position and a material condition.

Consent and compulsion are blurred in this late capitalist vision, with hope as a value enforced through the subtle pressure of enablement. Those lacking a demonstrable desire to optimize and surmount structural

\footnotetext{
${ }^{12}$ Concerns around new eugenic approaches are particularly acute in the field of disability studies.
} 
and economic barriers are regarded as no less problematic than the low stock of old, but they are now increasingly targeted as culpable 'skivers'. As our research with early intervention policy proponents and practitioners has underlined, a 'hopeful ethos' drives an almost evangelical faith in the power of good mothering to produce better brains (Edwards et al 2015). The strapline of the Family Nurse Partnership program declares they are 'changing the world one baby at a time'. Meanwhile, a burdensome responsibility is transferred onto disadvantaged mothers to achieve the impossible and parent their children out of poverty.

Given these developments we would argue that it is neither desirable nor possible to divorce cutting edge biosocial research from its downstream implications. It is at this more diffuse level where, through the centuries, abuses and cruelties have been enacted in the name of science. The consequences of the new biosocial styles of thought are no less brutal, with, for example, family court professionals now routinely consulting crude interpretations of neuroscience to assess whether parents are fit to raise their children (White and Wastel 2013). And from here it is only a small leap to imagine a future in which such biosocial 'knowledge' is drawn on to determine reproductive rights, suggesting that we are considerably closer to the eugenic past than many are prepared to consider.

\section{Plasticity and the eugenic pull}

History of course never simply repeats itself. Instead old configurations and preoccupations become assembled in new ways, in this case rewritten through the optimism of plasticity and anti-determinism. Rather than acting as a crucial failsafe, routing the biologisation of social issues away from the disturbing reductive social engineering of the past, new scientific developments are being reinterpreted through long standing rationales and fixations. This argument is convincingly made by Mansfield and Guthman (2015) in relation to the promise of plasticity associated with epigenetics. As they explain, biological variation is foregrounded in this new science, but epigenetics moves beyond the infinite study of difference to search for causal mechanisms linking environmental exposures to bodily outcomes. As such, epigenetics centres on disruptions to 'normal', 'natural' states of development in examining how 'oppression gets under the skin'. But although attention is shifted away from individual genes to collective, environmental causes, work is driven by a eugenic logic to 'eliminate defects and purify life' (Mansfield and Guthman 2015; 16).

This highlights troubling continuities in biosocial theorising, particularly in terms of interpretations of impurity and deviation. As Mansfield and Guthman note, epigenetic science operates through heightened notions of abnormality, with environmental factors that modify gene function drawn on to explain a range of 'disorders' including obesity, antisocial behaviour, developmental delay, delinquency and reduced IQ. As with genetic determinism, epigenetics biologises this difference, applying normatively grounded categorisations of a superior normal verses inferior abnormal. From this perspective, the potential for current models of biosocial synthesis to generate new narratives of, and possibilities for social justice appear limited. The pull of an optimisation logic seems destined to replicate rather than contest gender and class reproduction. For example, when biological discourses around pregnancy and breastfeeding become 'social' they migrate toward centring accounts of the optimal female brain and 'normal' infant development, advocating family relationships that leave little scope for notions of gender plasticity.

Similarly troubling connotations emerge from an epigenetic biopolitics of race. While some hail post genomic science as offering an anti-essentialist account of the located and transgenerational material injuries of race (Fitzgerald et al 2014; Kuzawa and Sweet 2007; Rose and Rabinow 2006), others point to the way such developments have worked to intensify racialization of populations. For example, Mansfield (2012) highlights US environmental health policies to limit methylmercury exposure through fish consumption as an illustration of the way race is reconstructed as plastic, yet embodied through the 
practices of reproductive women. High fish intakes are perceived to pose a risk to the neurodevelopment of foetuses through epigenetic mechanisms, driving US regulatory agencies to issue advice to women of child bearing age. Such warnings work to position particular minority ethnic cultural dietary practices as deviating from 'normal' white consumption, responsiblizing and inscribing biologised difference in the process.

Nutrition then becomes a form of moleculer exposure (Landecker 2011). Women and their food choices are problematized and targeted, despite the miniscule molecular differences flagged as the endpoint of concern and the contention surrounding interpretations of threshold doses. This risk lens not only shifts responsibility for managing environmental health and pollution onto childbearing women, it also biologically produces race as a physical inferiority transmitted through the generations. As Mansfield suggests:

A women's abnormal racialized diet is written on her child's brain. Suddenly racialized differences in intelligence - long one of the key axes of racialization (McWhorter 2009) - become real (368)

This focus on marking out socially divided cultural practices through patterns in gene expression sustains a centuries old preoccupation with sorting and ranking populations according to their deviation from white, privileged norms. This is notwithstanding, a deeper historical embedding in the Western socio-religious psyche positioning women as responsible for the woes of the world.

Thus while postgenomic science offers new conceptualisations and possibilities, it is magnetically latching onto and reproducing established social orders rather than challenging them. As such, received optimism about biosocial potentials risks replicating rather than disrupting the myopia marking previous incarnations. The eugenics movement of the last century was characterised by its own hopeful ethos, with improvement of the genetic national profile through selective breeding championed by progressive intellectuals including feminists, Marxists and social reformers (Rose and Rose 2014). It is not comforting to know that an ideology of improvement during this time was so ingrained that the first wave of Nazi atrocities went largely unremarked upon in the West (Pichot cited in Rose and Rose 2014).

\section{A handmaidens tale?}

In making these points we are not doubting the contribution sociology could make to the research frameworks of the life sciences. On the contrary, many of the concerns we have raised highlight the need for such collaboration, but in a context where sociological insights and the politics of knowledge are reflected upon and taken seriously. Calls to 'shake up the social sciences' (Christakis 2013) by mining the new frontiers of bioscience can imply a markedly one sided endeavour in which social scientists abandon their critical instincts and work to further a natural science agenda (Davies 2014). Social scientists may be reluctant to take up a role that, as Pickersgill et al (2013) suggest might be interpreted as 'handmaiden' to the life scientists. It is also unclear why scientists would look to sociologists to interpret the social above social psychologists, with whom they share more intellectual ground. Acknowledgement of and interest in the social and emotional within the life sciences is occurring in a distinctly psychologised context in which soft skills', relational competence and empathy are envisaged as strategic techniques to better manage social encounters and further self-interest (Illouze 2008). It may be argued that there is nothing inherently wrong with this approach. But if the social patterns of domination and oppression traditionally addressed within sociology are left unaddressed, the discipline itself risks becoming marginalised (Edwards et al. 2012).

As we have laid out in this paper there are broader issues at stake than the future of sociology. While the social may now be recognised as an essential feature of human functioning at the level of biology, this insight is locking into place an individualistic lens of cooperation and negotiation, while displacing alternative political visions of solidarity, commonality and belonging. An ethic of self-transformational efficiency is rendering the biological social to solidify and make normative particular ways of being. More 
Accepted for publication by The Sociological Review on 12.3.16

specifically, a logic of capital demands we become better individuals, obscuring and delegitimising a social realm in which interdependence, care, altruism, kindness and humility may be valued above instrumental self enhancement. With this vanishing of the social comes a closing down of these other ways of being and living. 
Figure I: 'Different upbringings' from Miller (2010)

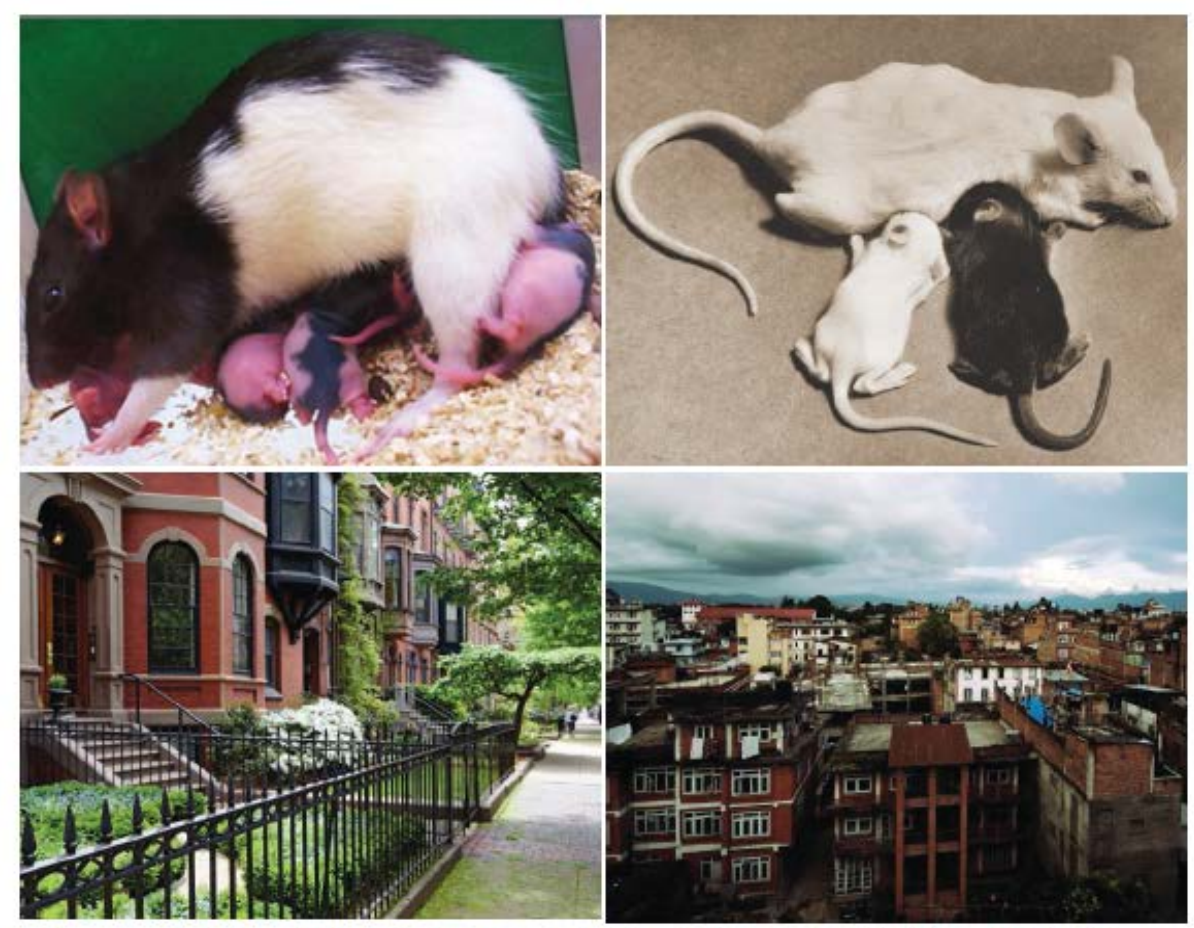

Different upbringings. Being raised by a nurturing (top left) or a lackadaisical (top right) mother can cause epigenetic differences that affect a rat pup's behavior later in life. Whether similar differences occur in people raised in wealthy (bottom left) or impoverished (bottom right) neighborhoods remains an open question.

From Miller, G. (2010) 'The seductive allure of behavioural epigenetics', Science, Vol. 329, 2 July, p.25. Reprinted with permission from AAAS. 


\section{References}

Becker, G. (1981) Treatise on the Family, Cambridge: Harvard University Press.

Becker G. (1964.). Human Capital: A Theoretical and Empirical Analysis, with Special Reference to

Education. Chicago, University of Chicago Press

Berlant, L. (2011) Cruel Optimism, Durham NC: Duke University Press.

Boltanski, L. and Chiapello, E. (2005) The New Spirit of Capitalism, London: Verso.

Bourdieu, P. and Wacquant, L. (1992) An Invitation to Reflexive

Sociology. Chicago: The University of Chicago Press

Bruer, J. (2011) Revisiting "The Myth of the First Three Years, Special Briefing for Monitoring Parents:

Science, Evidence, Experts and the New Parenting Culture,

http://blogs.kent.ac.uk/parentingculturestudies/files/2011/09/Special-briefing-on-The-Myth.pdf

Carey, N. 2012.The Epigenetics Revolution: How Modern Biology is Rewriting Our Understanding of

Genetics, Disease and Inheritance. London: Icon.

Catalano, R,F., Fagan, A. A., Gavin, L.E., Greenberg, M.T., Irwin, C.E., Ros, D. A. and Shek, D. T. (2010)

Worldwide application of prevention science in adolescent health, The Lancet, 379 (9826) p1653-1664.

Christakis, N. A. (2013) Let's Shake Up the Social Sciences, New York Times July 19th

http://www.nytimes.com/2013/07/21/opinion/sunday/lets-shake-up-the-social-sciences.html? $\quad \mathrm{r}=0$

Franks DD (2010) Neurosociology: The Nexus between Neuroscience and Social Psychology. New York: Springer.

Clery, E. (2012), 'Are tough times affecting attitudes to welfare?' (in Alison Park, Elizabeth Clery John

Curtice, Miranda Phillips and David Utting (eds), British Social Attitudes: The 29th Report, National Centre for Social Research

Cunha, F., Heckman, J., 2007. The technology of skill formation. American Economic Review 97 (2), 31-47

Davies, W. (2015) The Happiness Industry: How the Government and Big Business Sold us Well-Being, London: Verso.

Davies, W. (2014) The Limits of Neoliberalism. Authority, Sovereignty and the Logic of Competition, London: Sage.

Davies, W. (2014) Call to arms for shaking up social sciences relies on false premise that science alone can solve all social problems. LSE Impact Blog,

http://blogs.Ise.ac.uk/impactofsocialsciences/2014/10/14/shaking-up-social-sciences-false-premise-davies/

Davies, W. (2012) The Emerging Neocommunitarianism, Political Quarterly, 83 (4) 767-776,

Doidge, N. (2015) The Brain That Changes Itself: Stories of Personal Triumph from the Frontiers of Brain

Science, London: Penguin.

Edwards, R. and Gillies, V. (2016, forthcoming) 'Family policy: the Mods and Rockers', in H. Bochel and M.

Powell (eds) The Coalition Government and Social Policy, Bristol: Policy Press.

Edwards, R., Gillies, V. and Horsley, N. (2015) (Brain science and early years policy: Hopeful ethos or 'cruel optimism'? Critical Social Policy 35 (2) 167-187.

Edwards, R., Gillies, V. and Horsley, N. (forthcoming) Early Intervention: Who's Saving Children and Why? Bristol: Policy Press.

Edwards, R., McCarthy, J. and Gillies, V. (2012) 'The politics of concepts: family and its (putative?) replacements', British Journal of Sociology, 63(4): 730-746.

Faircloth, C., Layne, L. and Hoffman, D. (eds) (2013) Parenting in Global Perspective: Comparative Studies of Kinship, Self and Politics, Abingdon: Routledge.

Fitzgerald, D. and Callard, F. (2014) Social science and neuroscience beyond interdiciplinarity: experimental entanglements, Theory, Culture and Society, 32 (1) 3-32.

Fitzgerald, D., Rose, N. and Singh, I. (2014) Urban life and mental health: revisiting politics society and biology, Discover Society, Issue 5 http://discoversociety.org/category/issue-5/page/2/

Friedli, L. (2012) What we've tried, hasn't worked': the politics of assets based public health, Critical Public Health, 23:2, 131-145

Fuller, S. (2013) Preparing for Life in Humanity 2.0. London Paulgrave Macmillan. 
Fuller, S. (2014) Sociology as the Science of Human Uplift: A Once and Future Aspiration, British Sociological Association Keynote Address https://vimeo.com/103788571

Gane, N. (2014) Sociology and Neoliberalism: A Missing History. Sociology 48(6) 1092-1106.

Gillies, V. (2014) Troubling families: parenting and the politics of early intervention, in J.Pilcher and S. Wagg (eds) Thatcher's Grandchildren, Abingdon: Routledge.

Hartas, D. (2012) Inequality and the home learning environment: predictions about seven-year olds' language and literacy, British Educational Research Journal 38 (5) 859-879

Hartas, D. (2011) Families' social backgrounds matter: socio-economic factors, home learning and young children's language, literacy and social outcomes, British Educational Research Journal 37 (6) 893-914 Heckman, J.J., 2000a. Policies to foster human capital. Research in Economics 54 (1), 3-56.

Illouz, E (2008) Saving the modern soul: therapy, emotions and the culture of self-help, Berkeley: California Press.

Jones, R., Pykett, J. and Whitehead, M. (2013) Changing Behaviours: On the Rise of the Psychological State. Edward Elgar, Cheltenham.

Juengstemail, E., Fishman, J. R., McGowan, M. L, and Settersten Jr R. A. (2014) Serving epigenetics before its time, Trends in Genetics, 30 (10) 427-429

Law, J. and Urry, J. (2004) Enacting the social, Economy and Society, 33 (3) 390-410.

Kinsley, C. and Franssen, A. (2010) The Pregnant Brain as a Revving Race Car, Scientific American http://www.scientificamerican.com/article/pregnant-brain-as-racecarl

Kuzawa C.W. and Sweet E.(2009) Epigenetics and the embodiment of race: developmental origins of US racial disparities in cardiovascular health, American Journal of Human Biology, 21(1):2-15.

Landecker, H. (2011) Food as exposure: Nutritional epigenetics and the new metabolism, BioSocieties (2011) 6, 167-194.

McGowan, P., and Szyf, M. (2010). The epigenetics of social adversity in early life: implications for mental health outcomes. Neurobiology of Disease,39 (1) 66-72.

McVarish, J. (2014) 'Babies brains and parenting policy: the insensitive mother', in E. Lee, J. Bristow, C. Faircloth and J. McVarish (eds) Parenting Culture Studies, Basingstoke: Palgrave Macmillan.

Mansfield, B. (2012) Race and the new epigenetic biopolitics of environmental health BioSocieties 7 (4) 352-372.

Mansfield B and Guthman J. (2015) Epigenetic life: biological plasticity, abnormality, and new configurations of race and reproduction. Cultural Geographies 22(1): 3-20.

Massey, D.S., Rothwell, J.and Domina, T. (2009). 'The Changing Bases of Segregation in the United States'. The ANNALS of the American Academy of Political and Social Science 626: 74-90.

Massumi, B. 2002, Parables for the Virtual: Movement, Affect, Sensation, Durham, NC: Duke University Press.

Meloni, M (2014) How biology became social, and what it means for social theory, Sociological Review, 62 (3) 593-614.

Meloni, M. (2013) Biology without biologism: social theory in a postgenomic age, Sociology 48 (4) 731-746 Meaney, M. (2014) Epigenetics offer hope for disadvantaged children, Child and Family Blog, http://childandfamilyblog.com/epigenetics-offer-hope-disadvantaged-children/

Merzenich, M. (2013) Soft-Wired: How the New Science of Brain Plasticity Can Change Your Life, San Francisco: Parnassus Publishing.

Miller, G. (2010) 'The seductive allure of behavioural epigenetics', Science, Vol. 329, 2 July.

Monk, C. Spicer, J. Champagne, F.A. (2012) Linking prenatal maternal adversity to developmental outcomes in infants: The role of epigenetic pathways. Development \& Psychopathology 24(4): 1361-1376. Osborne, T., Rose, N. and Savage, M. (2008) Editors' Introduction: Reinscribing British sociology, some critical reflections, Sociological Review, 56 (4) 519-534

Pearson, R.M. and Lightman ( 2009) Emotional sensitivity for motherhood: late pregnancy is associated with enhanced accuracy to encode emotional faces, Hormonal Behaviour, 56(5):557-63. 
Petras, H. and Sloboda, Z ( 2014) An integrated prevention science model: a conceptual foundation for prevention research in Z. Sloboda and H. Petras, (Eds.) Defining Prevention Science. Advances in Prevention Science, New York: Springer.

Pickersgill, M. Niewohnerl, J, Muller, R. Martin, P and Cunningham-Burley, S. (2013) Mapping the new molecular landscape: social dimensions of epigenetics, New Genetics and Society, 32 (4) 429-447.

Puffet, N. (2016) Care Applications Hit Record High, Children \& Young People Now http://www.cypnow.co.uk/cyp/news/1156355/care-applications-hit-record-high

Pykett, J. (2013) "Neurocapitalism and the new neuros: using neuroeconomics, behavioural economics and picoeconomics for public policy, Journal of Economic Geography 13 (5), 845-869.

Rabinow, P. and Rose, N. (2006) Biopower today. BioSocieties 1(2): 195-217.

Rose, R. (2013) The Human Sciences in a Biological Age, Theory, Culture \& Society 30(1) 3-34.

Rose, N. and Abi-Rached, J.M. (2013) Neuro: The New Brain Sciences and the Management of the Mind, New Jersey: Princeton University Press.

Rose, N. and Novas, C. (2007) Biological Citizenship, in (eds A. Ong and S. J. Collier) Global Assemblages: Technology, Politics, and Ethics as Anthropological Problems, Oxford: Blackwell.

Rose, H. and Rose, S. (2014) Genes, Cells, and Brains: The Promethean Promises of the New Biology, London: Verso.

Rutter, M. (2007) 'Sure Start local programmes: an outsiders perspective', in J. Belsky, J. Barnes and E. Melhuish (eds) The National Evaluation of Sure Start: Does Area Based Early Intervention Work, Bristol: Policy Press.

Sandman C. A, and Glynn L.M. (2009) Corticotropin-Releasing Hormone (CRH) Programs the Fetal and Maternal Brain, Future Neurology, 4(3): 257-261.

Savage, M. and Burrows, R. (2007a) The coming crisis of empirical sociology, Sociology 41 (5) 885-99.

Savage, M. and Burrows, R. (2007b) Some further reflections on the coming crisis of empirical sociology, Sociology 43 (4) 762-72.

Savage, M. and Burrows, R. (2014) After the crisis? Big Data and the methodological challenges of empirical sociology Big Data and Society, http://bds.sagepub.com/content/1/1/2053951714540280.

Soss, J., Fording, R. and Schram S. (2011) Disciplining the Poor: Neoliberal Paternalism and the Persistent Power of Race, Chicago: University of Chicago Press.

Thrift, N. J. 2007, Non-Representational Theory: Space, Politics, Affect, London: Routledge

White, S. and Wastell, D. (2013) A Response to Brown and Ward, 'Decision-Making within the Child's

Timeframe' Available at SSRN: http://ssrn.com/abstract=2325357 or http://dx.doi.org/10.2139/ssrn.2325357 White, S. and Wastel D. (2013) 'Blinded by neuroscience: social policy, the family and the infant brain, in D. Wastell, S. White and A. Lorek, The Child's Timeframe - A Neuro Scientific Perspective, London: 14 Grays Inn Square.

Welfare Weekly (2015) 213\% Rise In Disability Hate Crime 'Fuelled' By Benefits Propaganda, Say Campaigners http://www.welfareweekly.com/disability-hate-crime-fuelled-by-propaganda/. 